\title{
Pengembangan Aplikasi E-Jurnal Kalbisocio dan Kalbiscientia Kalbis Institute
}

\author{
Muhammad Rusli ${ }^{1)}$, Jullend Gatc ${ }^{2)}$, Annisa Alifah Wardhani ${ }^{3)}$ \\ Institue Teknologi dan Bisnis Kalbis \\ Jalan Pulomas selatan Kav 22 Jakarta Timur 13210 \\ ${ }^{1)}$ muhammad.rusli@kalbis.ac.id \\ 2)jullend.gatc@kalbis.ac.id \\ ${ }^{3)}$ annisa.wardhani@gmail.com
}

\begin{abstract}
Abstrak: Penelitian ini bertujuan untuk mengembangkan E-Jurnal Kalbisocio dan Kalbiscientia untuk meningkatkan kelancaran pengelolaan jurnal. Kalbisocio adalah jurnal ilmiah bidang manajemen dan komunikasi, sedangkan Kalbiscientia adalah jurnal ilmiah bidang sains dan teknologi, yang keduanya diterbitkan oleh Kalbis Institute. Pada saat ini pengelolaan jurnal dilakukan secara manual, sehingga tidak dapat dilakukan dengan baik sesuai harapan. Dengan menggunakan E-Jurnal yang dapat diakses secara online sehingga tim editor jurnal dapat selalu memantau pencapaian proses yang telah diperoleh dan melihat apa yang harus dilakukan supaya target dapat tercapai sesuai waktu yang telah ditentukan. Metode penelitian yang digunakan untuk mengembangkan e-jurnal adalah metode Protoyping. Dengan penelitian tersebut dapat dikembangkan e-journal yang sesuai dengan kebutuhan Kalbisosio dan Kalbiscienta, dan hasil penelitian ini menjadi sarana untuk melakukan aktivitas pengelolaan jurnal secara online bagi tim editor, reviewer, dan penulis.
\end{abstract}

Kata kunci: e-jurnal, Kalbiscientia, Kalbisocio, protyping

\begin{abstract}
The aim of this research is developing e-jornal for journal Kalbisocio that focuses in management and communication science, and Kalbiscientia that focuses in science and technology. They are published by Kalbis Institute. The journal management is run by the publisher manualy, therefore the publication cannot be worth and realize. Enhancing to manage the journals, is should be an e-journal that assists all the editor team, reviewer, and author to do thier activities. The e-jurnal can be accesed and manage online by editor team, reviewers, and authors. Hence editor team can control all article processing and decide what to do with their problem in order that the articles can be published on time. Developing e-journal will use prototyping method that meets the need of Kalbisocio and Kalbiscientia. The research will develop an e-journal which assist all editor team, reviewers, and authors to do their activities in journal management.
\end{abstract}

Keywords: e-jurnal, Kalbiscientia, Kalbisocio, protoyping

\section{PENDAHULUAN}

Jurnal yang ada sekarang merupakan terbitan berkala dengan bentuk booklet atau buku berseri yang berisi bahan yang sangat diperlukan orang saat diterbitkan. Apabila dikaitkan dengan kata ilmiah di belakang kata jurnal maka hal tersebut dapat merupakan terbitan berkala dengan isi bahan ilmiah sebagai sumber informasi utama yang sangat penting di dalam perkembangan ilmu pengetahuan terutama untuk penelitian. Publikasi artikel yang ada di dalam jurnal merupakan syarat yang harus dipenuhi untuk memperoleh gelar Sarjana, Magister, maupun Doktor [1]. Dalam sistem penerbitan jurnal melibatkan empat pihak yaitu kustomer, penulis, penerbit, dan percetakan. Kustomer adalah pengguna atau pelanggan jurnal yang berkepentingan akan isi dan bentuk fisik jurnal. Penerbitan suatu jurnal dilakukan melalui beberapa tahap, yaitu tahap pengolahan naskah, tahap pengolahan desain dan tahap pencetakan. Pengelolaan jurnal memerlukan sumber daya manusia yang memiliki berbagai kompetensi seperti penyuntingaan dan desain, serta menggunakan perangkat lunak desktop publishing profesional. Penerbit biasanya mempunyai beberapa bagian yang menangani pengolahan jurnal pada tahap editorial. Dengan perkembangan desktop publishing pekerjaan bagian pracetak yang termasuk dalam percetakan pada saat ini dilakukan oleh penerbit. Bagian ini disebut pengolahan desain, 
atau bagian produksi, atau juga tetap menggunakan nama pracetak. Bagian pengolahan desain (pracetak) pada penerbit bertugas membuat desain dan layout halaman jurnal yang disiapkan untuk percetakan [2]. Tidak jarang bagian ini menangani pembuatan film dari hasil layout, sehingga bahan yang diserahkan kepada percetakan berupa film. Namun dengan perkembangan teknologi pada saat ini pencetakan tidak memerlukan film sehingga bagian desain menghasilkan file dalam format pdf untuk diserahkan kepada percetakan. Cara demikian dilakukan untuk mempertahankan kualitas jurnal yang akan dicetak, karena keakuratan hasil cetakan dapat dikendalikan oleh penerbit. Dengan demikian bagian pracetak di percetakan yang sebelumnya menangani pembuatan layout dan film sekarang hanya mengatur imposisi dan membuat plate untuk pencetakan. Im[osisi yaitu pengaturan halaman-halaman yang akan mengisi satu lembar kertas pada pencetakan. Beberapa lembar kertas tersebut kemudian dilipat dan dijilid untuk menghasilkan satu jurnal.

E-Journal yang kita kenal sekarang merupakan terbitan serial seperti bentuk tercetak dalam bentuk elektronik yang bentuknya terdiri: yaitu format teks, format teks dan grafik, serta format gambar. Dalam penggunaan layanan yang baik, tentunya setiap perpustakaan yang ada perlu menyediakan e-journal dalam bentuk online yang memudahkan para pembaca yang merupakan sumber informasi mudah diakses. Manfaat E-journal untuk penelusuran dari satu jurnal ke jurnal yang lain lebih cepat dan tepat, tidak membutuhkan waktu yang lama. Dapat disimpulkan bahwa e-journal merupakan jurnal ilmiah yang bisa dengan mudah. E-journal yang kita kenal sekarang pada dasarnya berbentuk HTML maupu bentuk PDF serta ada yang dalam bentuk multimedia yang merupakan pendukung e-journal dengan bentuk: animation, video dan interactivity [3].

E-journal memuat informasi yang up to date, current dan mutakhir ini berarti kandungan e-journal baru begitu pula informasinya bisa dipercaya karena memiliki semua informasi yang diperlukan seperti : nama penulis, jenis jurnal, jurnal fulltext dan abstrak demikian pula alamat e-mail penulis tercantum di dalam database. Adapun kelebihan dari Jurnal elektronik dibandingkan denga jurnal yang dicetak adalah kemutakhiran, kecepatan, dan penerimaan informasi jauh lebih cepat. Jurnal elektronik [4].

Perguruan tinggi banyak menerbitkan jurnal untuk memfasilitasi mahasiswa dalam rangka memenuhi persyaratan yang telah ditentukan untuk dapat memperoleh gelar sarjana, magister, maupun doktor. Pengelolaan jurnal yang dilakukan masih belum baik dan jauh dari sempurna, karena beberapa hal yaitu: Masih dilakukan secara konvensional; Kualitas artikel yang ditulis tidak memperhatikan gaya penulisan (gaya selingkung) yang berlaku pada jurnal tersebut; Struktur pengelolaan jurnal yang kadang kadang hanya sebagai kelengkapan persyaratan jurnal, namun tidak pernah bekerja sebagai editor; Anggota tim editor yang tidak semuanya berpengalaman dalam pengelolaan jurnal; Anggota tim editor yang sering berganti-gantu dalam kurun waktu relatif singkat; Tugas sebagai editor yang merupakan pekerjaan tambahan sehingga akan lebih mengutamakan tugas pokoknya; dan Pengelolaan jurnal belum menggunakan perangkat lunak desktop publishing profesional.

Dengan adanya kendala tersebut banyak penerbitan jurnal yang tidak sesuai jadwal yang telah ditentukan, bahkan kekurangan naskah final yang dapat diolah oleh bagian desain untuk diterbitkan. Jika naskah yang diterima oleh redaksi dari penulis mencukupi, namun setelah diteliti terdapat kekurangan yang harus dikembalikan kepada penulis karena redaksi tidak dapat mengatasi sendiri, sedangkan waktu penerbitan tidak boleh ditunda.

\section{METODE PENELITIAN}

\section{A. Pendekatan dan Metode Penelitian}

Menurut R. S. Pressman [5], perancangan sistem yang dikembangkan dapat menggunakan metode prototype. Metode dapat digunakan untuk mengembangakan sebuah perangkat yang tentunya dapat dikembangkan kembali. Metode yang digunakan dimulai dengan pengumpulan semua

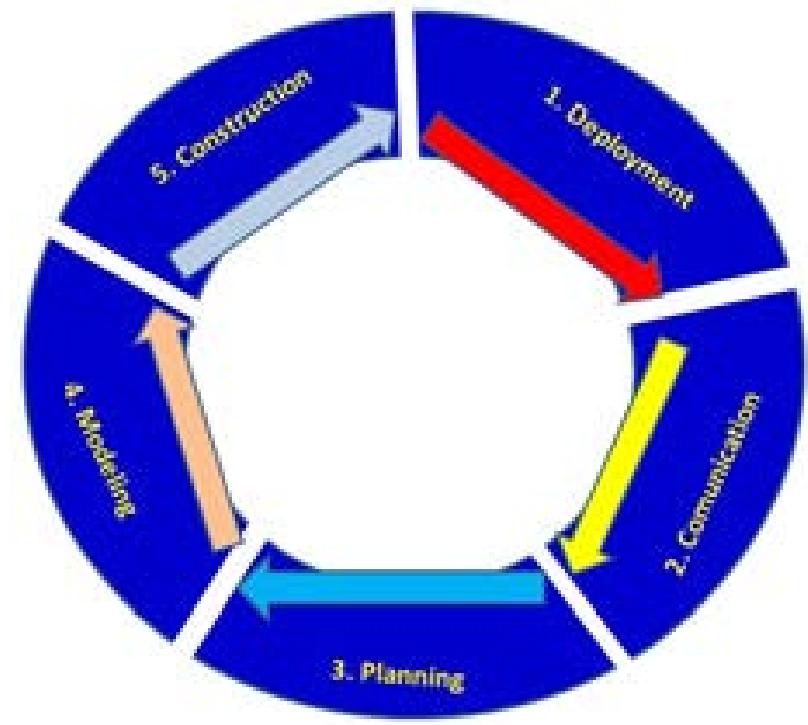

Gambar 1 Model prototype [5] 
kebutuhan dari pengguna, dengan kata lain pengguna dari perangkat yang dikembangkan adalah E-Jurnal, dengan membuat suatu rancangan yang dievaluasi kembali sebelum digunakan. Protoype sesuatu yang akan dievalusi dan dimodifikasi kembali. Setiap perubahan terjadi pada prototype telah dibuat berguna untuk memenuhi kebutuhan pengguna yang pada saat bersamaan memungkinkan pengembang untuk melihat apa saja kebutuhan pengguna secara baik. tertuang pada Gambar 1.

Berikut adalah tahapan metode prototype: 1) Deployment, customer atau user yang berminat untuk membuat suatu sistem membutuhkan pengembang sistem, yang dapat membuatkan suatu sistem dengan memaparkan kebutuhan sistem yang akan digunakan; 2) Comunication Selanjutnya, pengembang menginformasikan kepada pembuat software bahwa yang diinginkan harus memiliki kemampuan sesuai yang diinginkan user; 3) Planning, adalah merencanakan atau membuat perencanaan yang ingin dibuat sesuai dengan yang diinginkan si user tersebut; 4) Modeling Setelah melakukan planning, maka sang pembuat software/sistem melakukan perancangan model, contohnya model form awal atau $\log$ in usernya, maupun perancangan model form-form selanjutnya; dan 5) Construction, adalah tahap akhir di dalam prototyping model, dimana yang membuat software harus sesuai dengan perangcangan model dari suatu sistem yang ingin dibuat.

\section{B. Jurnal}

Jurnal yang ada sekarang yang bisa dilihat dan bisa dibaca adalah Publikasi ilmiah yang merupakan hasil dari penelitian yang dilakukan oleh mahasiswa dengan bentuk skripsi ataupun hasil penelitian dosen dengan mengikuti aturan-aturan tertentu yang ditetapkan oleh lembaga penelitian yang ada di kampus berbeda dengan lembaga lain, publikasi tersebut disebut jurnal. Informasi atau keterangan-keterangan dari publikasi ilmiah sepatutnya mengandung ilmu pengetahuan terbaru, maupun pengembangan dari suatu gagasan atau ide dengan memuat usulan [5]. Dengan demikian jurnal yang akan dibaca harus memuat pengetahuan yang relatif baru serta memuat informasi perkembangan ilmu pengetahuan .

Jurnal ada dua bentuk yang ada sekarang yaitu: tercetak yaitu jurnal yang diterbitan dalam periode tertentu berbentuk majalah atau dalam bentuk buku yang bisa diperoleh diperpustakan. Jurnal elektronik adalah jurnal yang diterbitkan dalam periode tertentu dalam bentuk elektronik. Jurnal yang kita kenal sekarang formatnya ada tiga: yaitu format teks, format teks dan format grafik, serta format full image. Adapun menurut LIPI [6], "Jurnal elektronik atau yang lebih dikenal dengan nama E-Journal yang kita kenal sekarang merupakan suata sarana yang berbasis website yang digunakan untuk mengelola suatu jurnal yang ilmiah maupun yang tidak ilmiah. Sarana ini sangat dibutuhkan yang merupakan suatu wadah untuk yang mengelola jurnal, author maupun pembaca karya ilmiah." Sedangkan Lasa [7] mengatakan bahwa dalam proses penerbitan e-journal dimulai dari penerimaaan artikel jurnal dari author, direview, mengembalikan artikel ke author, penyampaian hasil review, hasil perbaikan artikel, pengeditan dan layout, penerbitan sampai kepada distribusinya semua akan dilakukan secara online dengan memanfaatkan teknologi informasi. Mengapa jurnal elektronik muncul dilatar belakangi oleh mahalnya biaya yang diperlukan untuk cetak jurnal, demikian juga dengan kemajuan teknologi komputer serta sangat luasnya cakupan teknologi jaringan world wide web (www).

Dengan banyaknya kelebihan dari jurnal elektronik bisat lebih memudahkan oleh setiap pembaca didalam mencari informasi khususnya dalam hal pencarian jurnal elektronik. Namun demikian setiap jurnal elektronik juga pasti ada kelemahan dimana untuk mengakses jurnal elektronik harus melalui media yaitu komputer atau gadget yang membutuhkan layanan internet yang tentunya membutuhkan listrik, jika paket tidak ada atau listrik tidak ada maka jurnal elektronik juga tidak dapat diakses [8].

\section{Content Management System}

Content Management System (CMS) adalah perangkat lunak yang dapat digunakan untuk menambahkan ataupun memanipulasi isi dari suatu situs website, dalam pengelolaan dan mengadakan perubahan dari suatu website dinamis walaupun penulis maupun editor tidak dibekali oleh pengetahuan mengenai hal yang sifatnya teknis. Dari pengertian di atas maka setiap orang, penulis maupun editor, bisa menggunakan secara bebas untuk membuat, menghapus atau bahkan memperbaharui isi website sendiri walaupun tidak memiliki pengetahuan khusus menegenai website. CMS sifatnya adalah memisahkan antara isi dan desain, serta selalau konsisten dalam tampilan. Setiap bagian dari suatu website akan dapat memiliki isi maupu tampilan yang berbedabeda, walaupun demikian tidak harus khawatir akan kehilangan identitas dari website tersebut. Yang perlu kita ketahui adalah semua data yang tersimpan dalam satu tempat yang sudah ditentukan, jika data tersebut 
diperlukan maka dengan mudah dapat digunkan. Fleksibilitas yang diberikan oleh CMS didalam mengatur alur kerja atau 'workflow' dan hak akses, sehingga pengguna memperoleh kesempatan untuk berpartisipasi dari didalam pengembangan website. website yang dikelola akan sangat menguntungkan yang memiliki kompleksitas yang tinggi dan mengalami kemajuan yang cukup pesat [9].

\section{Penelitian Terdahulu}

Penelitian sebelumnya berjudul Multimedia Based Scoreboard Development of Four Disciplines of Execution for Journal Publication penelitian tersebut dilakukan oleh Rusli \& Hadi Tahun 2016. Penelitian tersebut sudah diseminarkan di 2016 8th International Conference on Knowledge and Smart Technology (KST), Chiang Mai Tanggal 3-6 Februari 2016. Penelitian lainnya adalah Implementasi Pengembangan Visualisasi Scoreboard Untuk Four Disciplines Execution Pada Perangkat Mobile penelitian tersebut dilakukan oleh Rusli \& Hadi, 2016. Penelitian berikut adalah Perancangan dan Pembuatan Aplikasi Manajemen Publikasi Ilmiah Berbasis Online pada Jurnal SISFO oleh Y. P.W Simaremare, A. Pribadi dan R. P. Wibowo Tahun 2013 [10].

\section{HASIL DAN PEMBAHASAN}

\section{A. Kebutuhan Non Fungsional}

Kebutuhan non fungsional adalah merupakan kebutuhan yang menentukan kriteria yang dapat digunakan untuk menilai sebuah pengoperasian sistem, daripada perilaku-perilaku tertentu. Kebutuhan non fungsional kontras dengan persyaratan fungsional yang menentukan perilaku atau fungsi tertentu. Rencana untuk menerapkan kebutuhan non fungsional harus rinci dalam arsitektur sistem, dikarenakan non-functional requirement biasanya memiliki persyaratan Arsitektur yang signifikan [11].

Untuk Pengembangan Manajemen E-Jurnal Kalbisocio dan Kalbiscientia Kalbis Institute diperlukan proses instal Open Journal System sebagai berikut: 1) Download and unpack the OJS installation from the PKP website. OJS dapat di download pada website http://pkp.sfu.ca/ojs download; Adapun data yang didownload berupa file kompresi rar/zip. Unpack file ojs yang didownload menggunakan aplikasi seperti zip atau rar; 2) Prepare Your Environment for the Install. Buat direktori untuk OJS untuk menyimpan file pengajuannya; Memberi hak akses file, jalur path pada file config. inc.php; Konfiguras web server (koneksi script php sudah terhubung dengan SetUID). Pre-Installation dituangkan pada Gambar 1; 3) Configure Your Database Information. Membuat database untuk sistem yang akan digunakan; pastikan bahwa sistem memiliki pengguna basis data yang memiliki izin yang memadai untuk mengoperasikan database (phpMyAdmin); OJS dapat berjalan di berbagai jenis RDBMS, meskipun hanya PostgreSQL dan MySQL yang aktif diuji; Untuk MySQL, pembuatan database dan user melalui phpMyAdmin atau dengan Query MySQL. dituangkan pada Gambar 2; dan 4) Complete the Install from the Web. Konfigurasi pengaturan lokal situs Anda: bukan hanya lokal yang tersedia untuk pengguna Anda, tetapi juga opsi pengaturan karakter. Jika memungkinkan, ubah dua yang terakhir dari default (ditampilkan) ke "Unicode (UTF-8)". Kecuali server database Anda sangat tua, Anda tidak perlu mengalami masalah pengaturan opsi ini ke Unicode. Ini akan memastikan dukungan multibahasa yang lebih baik.

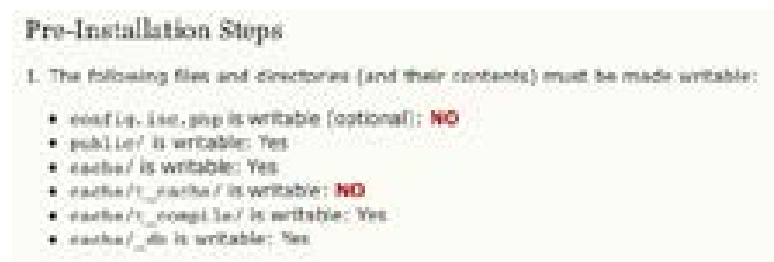

Gambar 1 Pre-Installation Steps

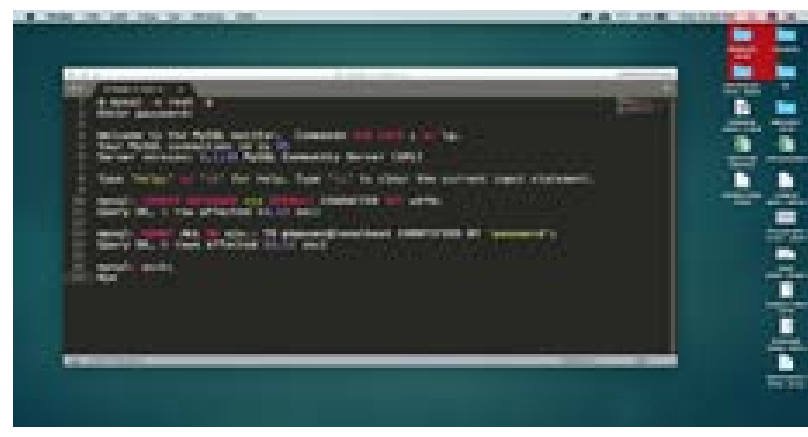

Gambar 2 Query MySQL

\section{B. Langkah-Langkah Instalasi Open Journal Syatem}

Langkah-Langkah Instalasi Open Journal Syatem: 1) Lakukan login pada hosting, buka icscit. com/cpanel. Masukkan username dan password; 2) Lalu akan muncul tampilan dashboard, kemudian pilih menu subdomain; 3) Maka akan muncul tampilan seperti dibawah ini, buat subdomain : kalbisjournal, kemudian isi bagian document root, jika sudah klik tombol create; 4) Kembali ke dashboard, kemudian buka submenu file manager; 5) Kemudian bukalah folder yang sesuai dengan nama subdomain yang telah dibuat (kalbisjournal.icscit.com), klik tombol 
upload diatas untuk menambahkan file ojs yang akan diinstall, Klik select file, kemudian pilih file ojs3 yang masih dalam format zip. Jika file sudah selesai diupload maka akan muncul tampilan.; 6) Kemudian ekstrak file yang telah diupload, pilih folder tujuan. Pastikan folder tujuan sesuai dengan document root dari subdomain yang telah dibuat; 7) Kemudian pindahkan file hasil ekstraksi ke folder yang sesuai dengan folder document root (kalbisjournal.icscit. com/ojs3). Setelah itu Buat folder files diluar folder ojs; 8) Kembali ke dashboard, kemudian buat database pada submenu database manager. Isi dengan nama KalbisJournal; 9) Setelah itu buat user untuk database, gunakan nama yang sama dengan database yg telah dibuat (KalbisJournal). Isi password pada kolom yang telahh disediakan; 10) Berikan hak user untuk database dengan cara mengisi nama user dan sesuaikan dengan nama database yang telah ditentukan; Pilih all privilleges, kemudian klik change/ok pada bagian bawah halaman; 11) Jika proses pembuatan domain, ekstraksi data, dan pembuatan database telah dilakukan, kemudian buka subdomain yang telah dibuat : kalbisjournal.icscit. com. Kemudian masukkan data pada form yang telah disediakan, jika sudah klik install, (host disesuaikan dengan subdomain yg telah dibuat, username, password, dan database name sesuaikan dengan yang telah dibuat. Jangan ceklis create new database, karena sudah terlebih dahulu membuat database pada langkah sebelumnya, pada kolom OAI merupakan default); 12) Kemudian jika sudah berhasil akan muncul tampilan seperti berikut ini. Klik login untuk masuk ke halaman utama OJS3, Kemudian isikan username dan password sesuai dengan yang telah dibuat saat proses instalasi; 13) Setelahnya akan mengarahkan anda ke halaman utama admin, klik create journal untuk menambahkan journal yang akan dibuat; 14) Kemudian isi kolom kolom yang ada sesuai dengan data yang dimiliki; 16) Kemudian anda akan diarahkan ke setting wizard pada journal yang telah dibuat, isikan kolom sesuai dengan data yang dimiliki, jika sudah click continue; dan 17) Jika sudah selesai, klik tombol view site pada bagian pojok kanan atas. Maka halaman utama dari jurnal akan muncul.

\section{Business Proces OJS}

Open Journal System adalah sebuah sistem manajeman konten berbasis web yang khusus dibuat untuk menangani keseluruhan proses manajemen publikasi ilmiah dari proses call for paper, peer review, hingga penerbitan dalam bentuk on-line [12]. Sebelum memulai, pahami dulu sedikit alur proses

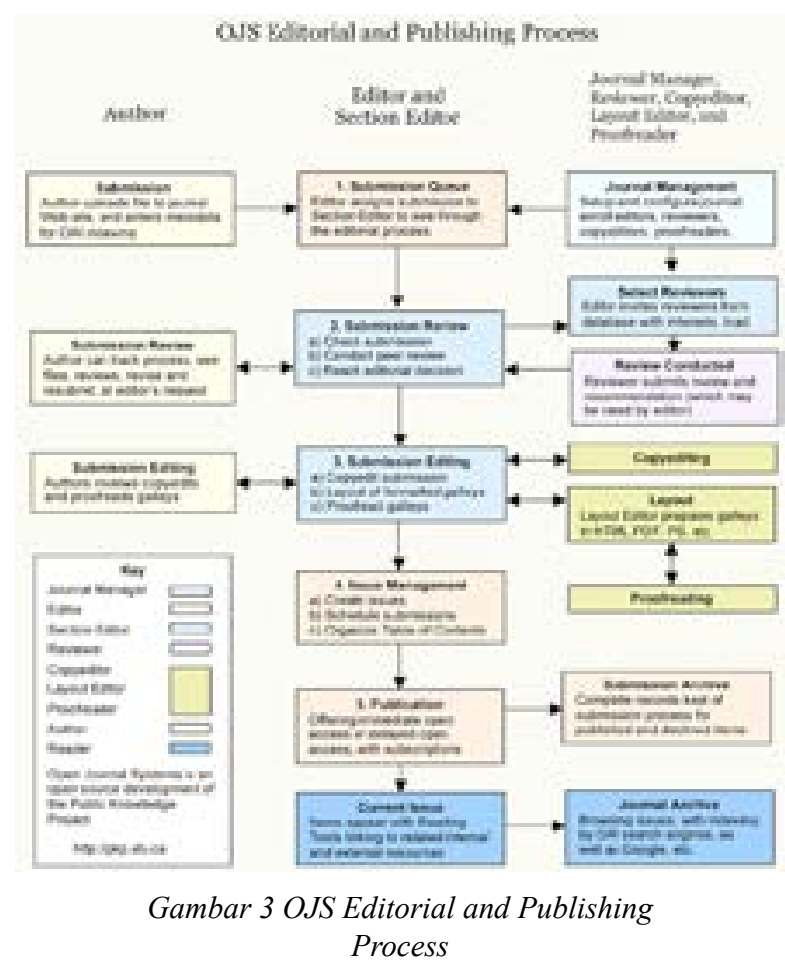

penerbitan jurnal di OJS dituangkan pada Gambar 3.

Dari Gambar 3 dapat dijelaskan proses singkat yang biasanya berjalan pada sebuah ejournal adalah sebagai berikut [14]: 1) Author membuat account setelah account jadi, author mensubmit artikel jurnal ilmiah untuk dipublish; 2) Author bisa memeriksa kemajuan sampai dimana proses artikelnya, apakah sudah review, kemudian perbaikan revisi setelahnya resubmit lagi; 3) Editor memeriksa semua artikel jurnal yang masuk, kemudian menyerahkan ke reviewer untuk direview jurnal tersebut; 4) Editor memeriksa apakah reviwer merekomendasikan artikel jurnal tersebut atau tidak, jika direkomendasikan artinya artikel tersebut bisa dilanjutkan, atau ada perbaikan maka artikel dikembalikan ke author untuk ditambahkan kemudia disubmit kembali, jika artikel jurnal ditolak artinya tidak bisa dilanjutkan ke jurnal yang bersangkutan; 5) Editor melakukan submit editing dari mulai edit format, menglayout galleys, serta melakukan profread; Editor membuat atau menuliskan volume, nomor terbitan, tanggal terbitan serta tahun terbitan dari jurnal yang dikelola, kemudian membuat daftar isi dari jurnal tersebut; 7) Editor harus mengarsifkan semua proses pengelolaan jurnal mulai dari penerimaan artikel jurnal sampai artikel jurnal tersebut layak untuk publish; 8) Jika proses jurnal semua sudah dilakukan maka maka editor dari jurnal tersebut bisa melakukan proses publish dengan memilih volume, nomor, tanggal serta tahun terbit dari jurnal tersebut; 9) Jika jurnal yang dikelola sudah dipublish, maka pengelola jurnal mendaftarkannya ke situs pengindex jurnal. 
Untuk instalasi Open Journal System Pengembanagan E-Jurnal Kalbisocio dan Kalbiscientia Kalbis Institut adalah sebagai berikut: 1) Proses editorial: Submission Queue; Submission Review; Submission Editing; Scheduling Queue; Table of Content; 2) Author: selain menulis artikel jurna author juga bisa mendaftarkan jurnal yang ditulis melalui web; dan 3) Proses Entry Data Jurnal: Dilakukan oleh author; Ada 5 langkah yaitu start, enter metadata, upload submission, upload supplementary files, confirmation; Log in ke Open Journal System; Pilih peran author

\section{Hasil Instalasi Open Journal System}

Dari hasil instalasi open journal system maka diperoleh dua buah jurnal dengan system online jurnal yaitu jurnal Kalbisscio dan jurnal Kalbiscientia yang tampilannya dituangkan pada Gambar 4; Untuk tampilan Kalbiscientia dituangkan pada Gambar 5; dan Untuk tampilan Kalbiscientia dituangkan pada Gambar 6.
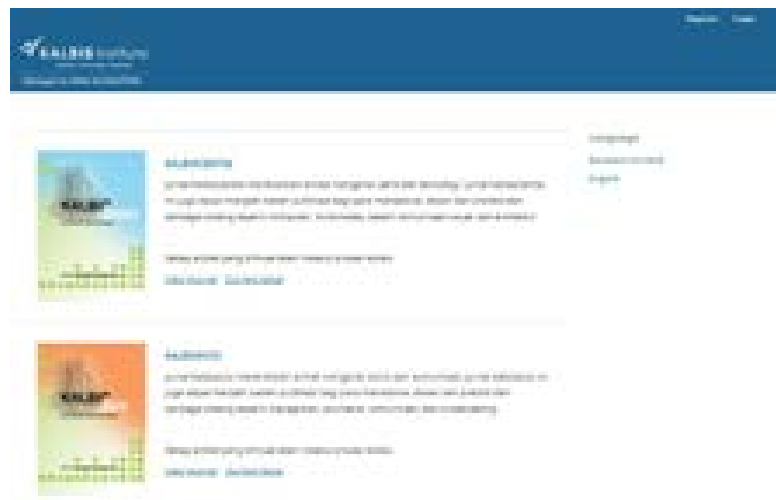

Gambar 4 Jurnal Kalbiscientia dan Jurnal kalbisocio

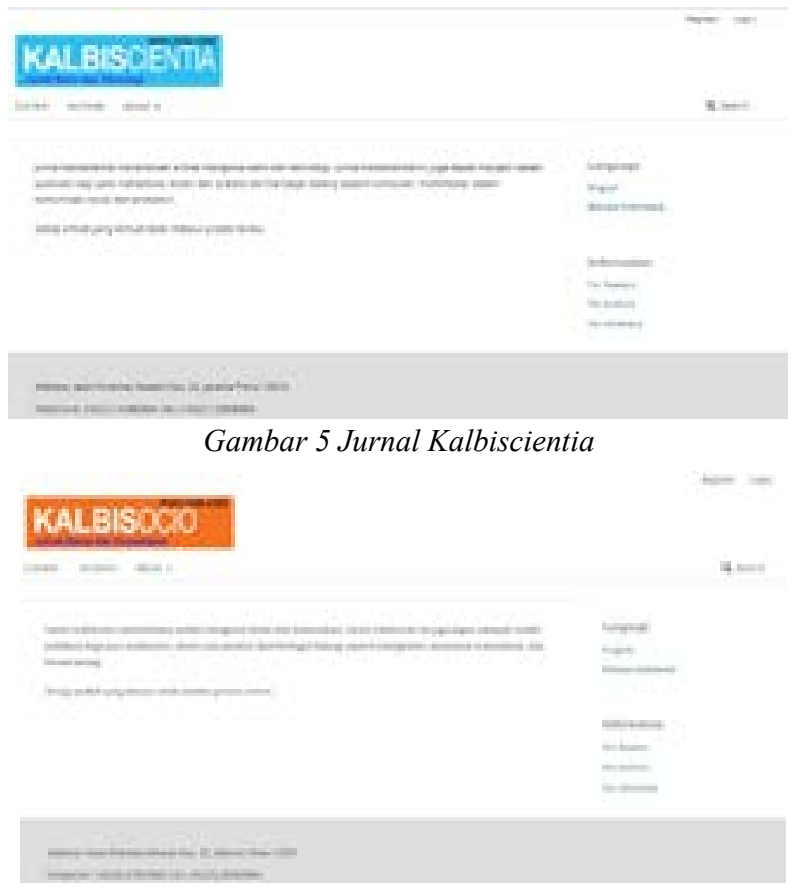

Gambar 6 Jurnal Kalbisocio

\section{SIMPULAN}

Kesimpulan yang dapat ditarik dari penjelasan di atas adalah: mengembangkan aplikasi E-Jurnal Kalbisocio dan Kalbiscientia untuk memudahkan akses dan publikasi secara luas ilmu dan pengetahuan para peneliti/penulis. Dengan menggunakan E-Jurnal tim editor jurnal dapat selalu memantau pencapaian proses yang telah diperoleh dan melihat apa yang harus dilakukan supaya target dapat recapai sesuai waktu yang telah ditentukan

\section{DAFTAR PUSTAKA}

[1] H. Sutopo, Menulis dan Mengelola Jurnal Bereputasi, Yogyakarta: Morfalingua, hlm 3, 2016.

[2] M. Rusli \& H. Sutopo, "Multimedia based scoreboard development of four disciplines of execution for jurnal publication," dalam 2016 8th International Conference on Knowledge and Smart Technology (KST), Chiang May, hlm 1, 2016.

[3] A. D. Tresnawan, "Gina's Blog Komas," 2010. [Online]. Available: http://ginasblogkomas.co.id/2010/04/ jurnal-elektonik-berbagi-pengalaman.html. [Diakses 9 Desember 2016].

[4] R. S. Pressman, Pendekatan Praktisi Rekayasa, Yogyakarta: Andi Ofset, hlm 215, 2012.

[5] Lasa \& U. Suciati, Kepustakawanan Indonesia, Yogyakarta: Pustaka Book, hlm 135, 2009.

[6] M. Baihaqi dan A. Hanafi, "Perancangan dan Pembuatan E-Journal Menggunakan Open Journal System di STMIK Jendral Achmad Yani Yogyakarta," TEKNOMATIKA, vol. 7, no. E-Journal, hlm 30, 2015.

[7] K. Antonius, "Pengantar CMS," 2012. [Online]. Available: https://kyantonius.com/atwork/pengantarcms/. [Diakses 9 Desember 2016].

[8] D. H. Asy'ari, H. D. Fitriani \& S. Lugitha, "Jurnal Elektronik dan Buku Elektronik," 24 Desember 2016. [Online]. Available: https://hadiasyari.fileswordpress. com/2015/jurnalelektronik-dan-buku-elektronik.pdf. [Diakses 9 Desember 2016].

[9] L. I. P. Indonesia, "Jurnal Online Lembaga Ilmu Pengetahuan Indonesia,” 2015. [Online]. Available: https://bud1 nugroho.files.wordpress.com/2013/05/ panduan-jurnalonline-lipi-b.pdf.. [Diakses 9 Desember 2016].

[10] H. D. Sarjono, "Pengenalan dan Pengembangan E-Jurnal,” 2019. [Online]. Available: http://blog.uny. ac.id/hermansurjono/files/2009/09/Pengembangane-journal-herman-d-surjono-uny.pdf. [Diakses 9 Desember 2016] 
[11] Y. Simaremare, A. Pribadi \& R. P. Wibowo, "Perancangan dan Pembuatan Aplikasi Manajemen Publikasi Ilmiah Berbasis Online pada Jurnal SISFO," TEKNIK POMITS, vol. 2, hlm 470-475, 2013.

[12] S. N. Hayat, "Dictio," 20 Januari 2017. [Online]. Available: https://www.dictio.id/t/apa-yang-dimaksuddengan-kebutuhan-non-fungsional/3181. [Diakses 10 Maret 2018].

[13] "Open Journal System," 31 Agustus 2016. [Online]. Available: https://pkp.sfu.ca/ojs/. [Diakses 10 Maret 2018].
[14] M. D. Notes, "Cara Cepat Implementasi Open Journal System (OJS) untuk Jurnal Ilmiah,," 24 Oktober 2014. [Online]. Available: https://andykamt.com/cara-cepatimplementasi-open-journal-system-ojs-untuk-jurnalilmiah/. [Diakses 12 Maret 2018]. 